\title{
Primary cutaneous T-cell lymphoma: experience from the Peruvian National Cancer Institute*
}

\author{
Rosana Ruiz ${ }^{1}$ \\ Raul Mantilla ${ }^{2}$ \\ Luis Casanova ${ }^{3}$
}

\author{
Zaida Morante ${ }^{1}$ \\ Luis Mas ${ }^{1}$ \\ Henry L. Gomez ${ }^{1}$
}

DOI: http://dx.doi.org/10.1590/abd1806-4841.20176825

\begin{abstract}
BACKGROUND: Primary cutaneous T-cell lymphomas constitute a heterogeneous and rare group of diseases with regional particularities in Latin America.

Овлестіve: To determine the clinicopathological features, relative frequency and survival among patients from a Peruvian institution.

MethoDs: Primary cutaneous T-cell lymphomas were defined based on the absence of extracutaneous disease at diagnosis. Classification was performed following the 2008 World Health Organization Classification of Neoplasms of the Hematopoietic and Lymphoid tissues. Risk groups were established according to the 2005 World Health Organization-EORTC classification for cutaneous lymphomas. Data of patients admitted between January 2008 and December 2012 were analyzed.

RESULTS: 74 patients were included. Mean age was 49.5 years. In order of frequency, diagnoses were: mycosis fungoides (40.5\%), peripheral T-cell lymphoma not otherwise specified (22.95\%), adult T-cell lymphoma/leukemia (18.9\%), CD30+ lymphoproliferative disorders (6.8\%), hydroa vacciniforme-like lymphoma (5.4\%), extranodal NK/T-cell lymphoma (4.1\%) and Sézary syndrome (1.4\%). Predominant clinical patterns were observed across different entities. Mycosis fungoides appeared mainly as plaques (93\%). Peripheral T-cell lymphoma not otherwise specified and adult T-cell lymphoma/leukemia presentation was polymorphic. All patients with hydroa vacciniforme-like lymphoma presented with facial edema. All cases of extranodal NK/T-cell lymphoma appeared as ulcerated nodules/tumors. Disseminated cutaneous involvement was found in $71.6 \%$ cases. Forty-six percent of patients were alive at 5 years. Five-year overall survival was $76.4 \%$ and $19.2 \%$, for indolent and highrisk lymphomas, respectively $(\mathrm{p}<0.05)$. High risk group (HR: 4.6 [2.08-10.18]) and increased DHL level (HR: 3.2 [1.57-6.46]) emerged as prognostic factors for survival.
\end{abstract}

STUDY LIMITATIONS: Small series.

ConcLusion: Primary cutaneous T-cell lymphomas other than mycosis fungoides or CD30+ lymphoproliferative disorders are aggressive entities with a poor prognosis.

Keywords: Lymphoma, T-Cell, cutaneous; Peru; Prognosis; Survival

\section{INTRODUCTION}

Primary cutaneous lymphomas (PCL) are monoclonal lymphoproliferative processes that affect skin, without evidence of extracutaneous involvement at diagnosis. ${ }^{1-3}$ This entity accounts for $18 \%$ of the extranodal non-Hodgkin lymphomas (NHL), being the skin the second most frequent location, following the gastrointestinal tract. 4,5 Worldwide, its annual incidence is $0.5-1$ per 100,000 habitants. ${ }^{4}$ In Peru, 35\% of NHL are extranodal. Of those, $10 \%$ to $15 \%$ are located on the skin. ${ }^{6,7}$ According to the cell of origin PCLs are classified as T-cell or B-cell ( $80 \%$ and $20 \%$, respectively). ${ }^{8}$

As primary cutaneous lymphomas constitute a heterogeneous and unusual group of diseases, they represent a diagnostic and therapeutic challenge. The correlation of clinical, pathological and immunophenotypic findings is imperative for its proper assessment and classification. ${ }^{1}$
Many attempts have been made to establish a classification system for cutaneous lymphomas that is widely accepted. ${ }^{9}$ In 2005 , the World Health Organization (WHO) and the European Organization for Research and Treatment of Cancer (EORTC) together established a primary cutaneous lymphoma classification system based on phenotypic and molecular features that enable to group them according to their prognosis. ${ }^{10}$ Regarding T-cell lymphomas, indolent entities with a good prognosis, whose five-years survival varies among $75 \%$ and $100 \%$ are: mycosis fungoides (MF) and its variants, CD30+ anaplastic large cell lymphoma, lymphomatoid papulosis and panniculitis-like T-cell lymphoma. Sézary syndrome, adult T-cell leukemia/lymphoma (ATLL), extranodal NK/T lymphoma (NTCL), nasal type and the peripheral T-cell lymphoma not otherwise specified (PTCL-NOS) are recognized as aggressive enti-

\footnotetext{
Received on 14.12.2016.

Approved by the Advisory Board and accepted for publication on 04.03.2017.

* Study conducted at the Instituto Nacional de Enfermedades Neoplásicas (INEN) - Surquillo, Peru

Financial support: None.

Conflict of interest: None.

Medical Oncology Service, Instituto Nacional de Enfermedades Neoplásicas (INEN) - Surquillo, Peru.

Education Department, Instituto Nacional de Enfermedades Neoplásicas (INEN) - Surquillo, Peru.

Medical Oncology Service, Instituto Oncológico Miraflores - Miraflores, Peru.
}

(C)2017 by Anais Brasileiros de Dermatologia 
ties. For the latter entities, survival ranges between $16 \%$ and $24 \%$. Years later, the 2008 WHO Classification of Neoplasms of the Hematopoietic and Lymphoid Tissues grouped hematologic diseases regardless of the organ of origin. ${ }^{8}$ It additionally considers entities that are not included in the specific skin classifications, such as the T-cell hydroa vacciniform-like lymphoma (HVL).

The present study aims to determine the clinicopathological features, the relative frequency and overall survival of the PCTCL patients of the Instituto Nacional de Enfermedades Neoplásicas (INEN) during the period 2008-2012.

\section{METHODS}

This was a retrospective-observational study which included patients aged $>14$ years diagnosed with PCTCL, admitted at INEN between January 2008 and December 2012.

PCL were defined based on the absence of extracutaneous disease at diagnosis (according to imaging assessment and evaluation of the bone marrow aspiration). ${ }^{2,3}$ Patients without histopathological confirmation of diagnosis at our institution were excluded, as well as patients who presented with secondary cutaneous involvement from a systemic disease or another primary location.

Information regarding age, sex, presence of B symptoms (fever for 3 consecutive days, weight loss $\geq 10 \%$ corporal weight in six months, drenching night sweats) and lymphadenopathies, type of lesion, extension of cutaneous involvement (localized or disseminated), lactate dehydrogenase (LDH) level, ionic calcium level and human T-lymphotropic virus 1 (HTLV-1) was collected and transferred to a data base. Entities were classified according to the 2008 WHO system and the risk-groups were established according to the 2005 WHO-EORTC classification for cutaneous lymphomas. ${ }^{8,10}$

Descriptive analysis was performed through frequency distribution tables. For overall survival (OS), the follow-up period was defined as the time elapsed between date of diagnosis and date of death or last contact. Survival curves were estimated using the Kaplan-Meier method and differences among curves within different variables were established with the log-rank test. A level of $p<0.05$ was considered for significant differences. The statistical package SPSS (IBM SPSS Statistics for Windows, Version 19.0. Armonk, NY: IBM Corp) was used for data analysis.

\section{RESULTS}

During the assessment period, 115 patients diagnosed with cutaneous lymphoma were admitted. Eighty-six corresponded to cutaneous T-cell lymphomas; 20, to cutaneous B-cell lymphomas; and, 9 to blastic plasmacytoid dendritic cell neoplasms. Three patients were excluded due to secondary cutaneous involvement and 9 because of the lack of histopathological diagnosis. The 74 PCTCL cases with confirmed histopathological diagnosis were finally included (Figure 1).

Median age was 49.5 years (range 15-90 years), with the highest incidence in the 40-49 age group. Women and men accounted for $51.4 \%(n=38)$ and $48.6 \%(n=36)$ of the cases, respectively. Most of the patients (44.6\%) came from the Highland region of the country. Presence of B symptoms was reported only in 5.4\% patients $(n=4)$. Pain and pruritus were found in $45.9 \%$ and $10.8 \%$ of cases, respectively. LDH level was abnormally increased in $36.5 \%$ of patients. One single patient presented a high calcium level.

The most common diagnoses were MF with 30 cases (40.5\%), followed by PTCL-NOS (22.95\%) and ATLL (18.9\%). CD30+ lymphoproliferative disorders, HVL, extranodal NTCL and Sézary syndrome accounted for $6.8 \%, 5.4 \%, 4.1 \%$ and $1.4 \%$ of the cases, respectively (Table 1).

Across the different entities, predominant clinical patterns were observed (Table 2). Even though MF appeared mostly as plaques (93\%) with ichthyosiform component and/or erythroderma, there were also nodule or tumor lesions in $40 \%$ and $20 \%$, respectively. PTCL-NOS presentation was polymorphic, while plaques predominated $(82 \%)$; nodules $(76 \%)$, tumors $(24 \%)$ and ulcers $(12 \%)$ were present in a significant number of cases. In ATLL plaques $(71 \%)$ and tumors $(43 \%)$ were the most frequent lesions. Four patients $(100 \%)$ with HVL presented with classical facial edema. Three cases of extranodal NTCL appeared as ulcerated nodules (100\%) and/or ulcerated tumors (65\%) (Table 2). Disseminated cutaneous involvement was found in $71.6 \%$ of cases and, in $28.4 \%$, the disease was confined into an anatomical region.

Thirty-one percent of patients did not receive any treatment at our institution. Most of MF patients (47\%) were treated topically with carmustine (BCNU) or corticosteroids. PTCL-NOS patients received systemic chemotherapy, radiotherapy or topical treatment, in $29 \%, 24 \%$ and $12 \%$ of the cases, respectively. ATLL cases were

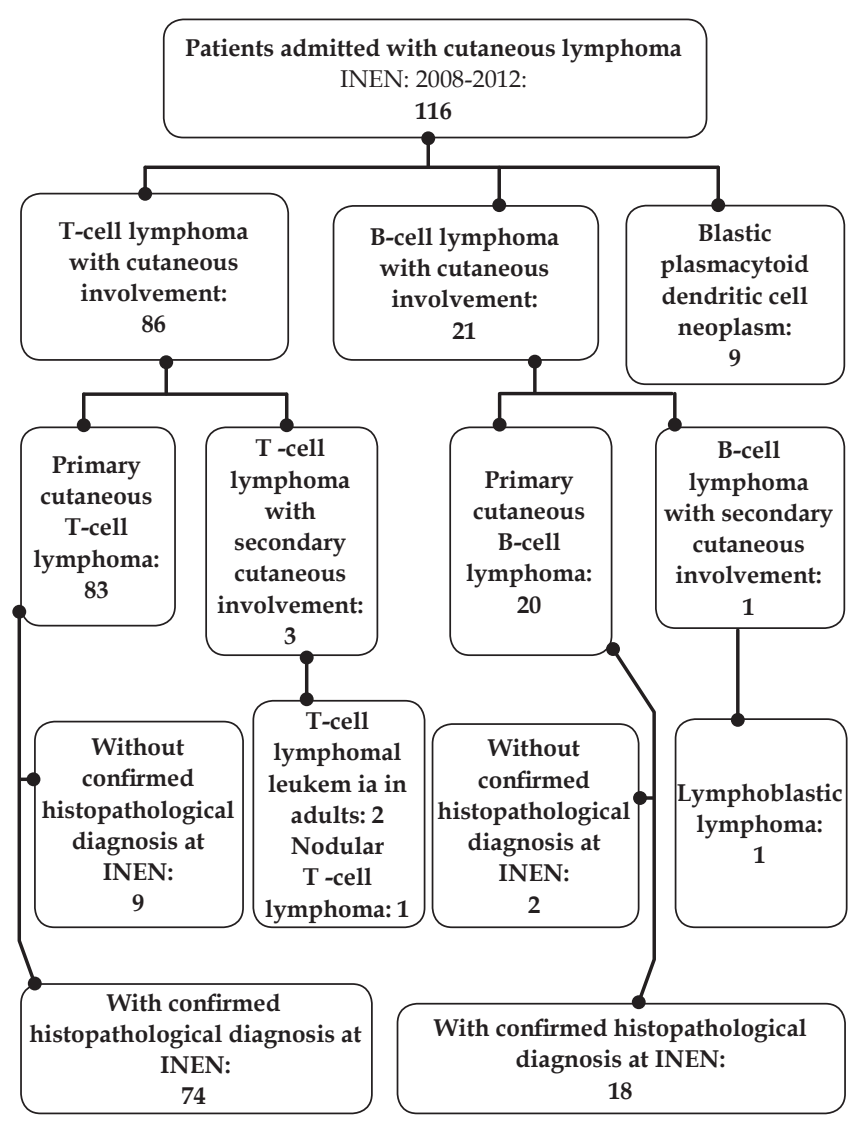

INEN, Instituto Nacional de Enfermedades Neoplásicas

Figure 1: Patients inclusion flowchart at INEN 
exclusively treated systemically $(75 \%)$, with chemotherapy or interferon-zidovudine, the other three cases did not receive any treatment. Likewise, two of the three extranodal NTCL patients received systemic treatment with chemotherapy.

Median follow-up period was 52 months. Five-year OS was estimated in $46.8 \%$ (Graph 1). Median survival time was 53 months. For the indolent or low risk lymphomas group (CD30+ lymphoproliferative disorders or MF), 5-year OS was 76.4\%. For the aggressive or high-risk lymphomas (ATLL, Sézary syndrome, NTCL or PTCL-NOS), 5-year OS was 19.2\% (Graph 2).

Five-year OS was 75.6\% for MF, whereas for ATLL and PTCL-NOS, it was $21.4 \%$ and $19.3 \%$, respectively (Graph 3). Three of the four patients with $\mathrm{HV}$ are alive to date. Three patients diagnosed

\begin{tabular}{lc}
$\begin{array}{l}\text { TABLE 1: Primary cutaneous T-cell lymphomas frequency and risk } \\
\text { group }\end{array}$ & Frequency \\
\hline $\begin{array}{l}\text { WHO classification of Neoplasms of the } \\
\text { hematopoietic and lymphoid tissues (2008) }\end{array}$ & $30(40.5)$ \\
\hline MF & $17(22.9)$ \\
\hline PTCL-NOS & $14(18.9)$ \\
\hline ATLL & $5(6.8)$ \\
\hline CD30+ Lymphoproliferative disorders & $4(5.4)$ \\
\hline Anaplastic lymphoma & $1(1.4)$ \\
\hline Lymphomatoid papulosis & $4(5.4)$ \\
\hline HVL & $3(4.1)$ \\
\hline Extranodal NTCL & $1(1.4)$ \\
\hline Sézary syndrome & Frequency \\
\hline \multicolumn{1}{|c|}{ Risk groups } & $(\%)$ \\
\hline $\begin{array}{l}\text { Indolent lymphomas: CD30+ Lymphoproliferative } \\
\text { disorders, MF }\end{array}$ & $35(47.3)$ \\
\hline $\begin{array}{l}\text { Aggressive lymphomas (ATLL, Sézary syndrome, } \\
\text { extranodal NTCL, PTCL-NOS) }\end{array}$ & $35(47.3)$ \\
\hline *Variable behavior lymphomas (HVL) & $4(5.4)$ \\
\hline
\end{tabular}

MF: Mycosis fungoides, PTC NOS, ATLL: Adult T-cell leukemia/lymphoma, HVL: Hydroa vacciniforme like-lymphoma, NTCL: NK/T-cell lymphoma.

*Not included in the 2005 EORTC-WHO. with extranodal NTCL died because of the disease.

In the univariate analysis, high risk group (HR: 4.6 [2.0810.18]) and increased DHL level (HR: 3.2 [1.57-6.46]) were prognostic factors associated with survival. No significant relation was found with other factors such as age and extension of disease.

\section{DISCUSSION}

Out of the 92 primary cutaneous lymphoma cases, T-cell lymphomas accounted for $80.4 \%$ of cases and B-cell lymphomas, for the remaining ones. These results are similar to those previously reported by Latin-American institutions. A Peruvian study and another study conducted in Brazil reported that T-cell lymphomas represented $83.4 \%$ and $84.7 \%$ of primary cutaneous lymphoma cases, respectively. ${ }^{11,12}$ Similarly, Asian publications show a clear predomi-

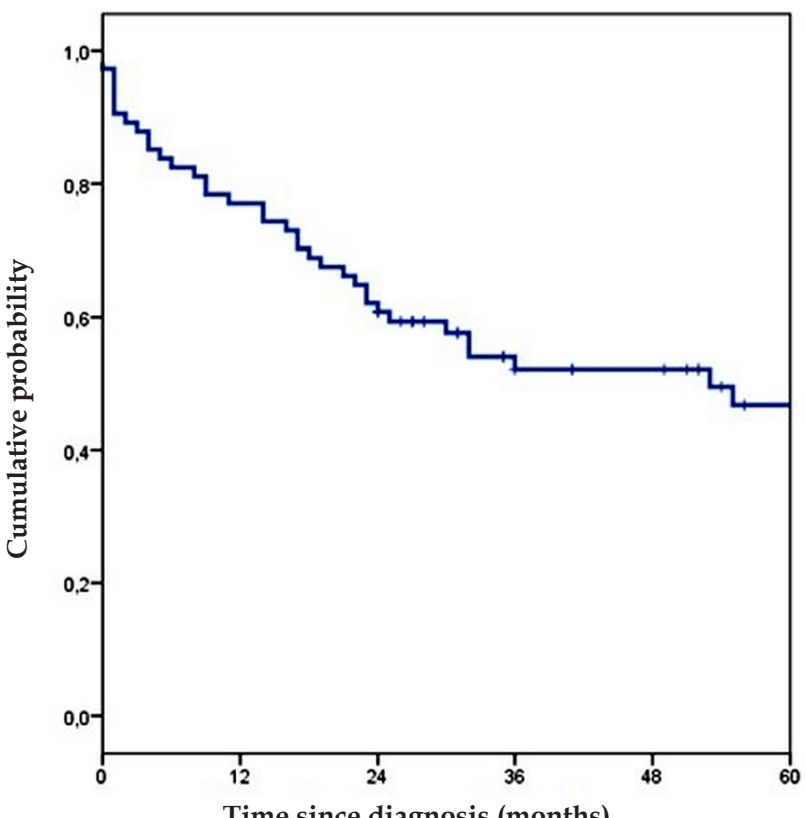

$\begin{array}{ccccccc}\text { OS: } & 100 \% & 77 \% & 60.8 \% & 52.1 \% & 52.1 \% & 46.8 \% \\ \mathrm{n}: & 74 & 57 & 46 & 28 & 24 & 16\end{array}$

GRAPH 1: Primary cutaneous T-cell lymphoma overall survival

\begin{tabular}{|c|c|c|c|c|c|c|c|c|c|c|c|c|c|c|}
\hline & \multicolumn{2}{|c|}{ Plaques } & \multicolumn{2}{|c|}{ Ichthyosiform } & \multicolumn{2}{|c|}{ Nodule } & \multicolumn{2}{|c|}{ Tumor } & \multicolumn{2}{|c|}{ Erythroderma } & \multicolumn{2}{|c|}{ Ulcer } & \multicolumn{2}{|c|}{ Facial edema } \\
\hline & Freq & $(\%)$ & Freq & $(\%)$ & Freq. & $(\%)$ & Freq. & $(\%)$ & Freq & $(\%)$ & Freq & $(\%)$ & Freq & $(\%)$ \\
\hline MF & 28 & (93) & 21 & (70) & 12 & $(40)$ & 6 & (20) & 17 & (57) & 1 & (3) & 0 & (0) \\
\hline PTCL-NOS & 14 & $(82)$ & 12 & $(71)$ & 13 & (76) & 4 & (24) & 7 & $(41)$ & 2 & $(12)$ & 0 & (0) \\
\hline ATLL & 10 & (71) & 5 & (36) & 4 & (29) & 6 & (43) & 5 & (36) & 0 & $(0)$ & 0 & (0) \\
\hline CD30+ & 2 & $(40)$ & 3 & $(60)$ & 2 & $(40)$ & 3 & (60) & 1 & $(20)$ & 1 & $(20)$ & 0 & (0) \\
\hline HVL & 3 & (75) & 3 & (75) & 3 & (75) & 0 & (0) & 1 & $(25)$ & 2 & $(50)$ & 4 & (100) \\
\hline NTCL & 1 & (33) & 0 & $(0)$ & 3 & $(100)$ & 2 & (67) & 0 & $(0)$ & 3 & $(100)$ & 0 & $(0)$ \\
\hline Sézary & 1 & (100) & 1 & (100) & 1 & $(100)$ & 0 & $(0)$ & 1 & $(100)$ & 0 & $(0)$ & 0 & (0) \\
\hline Total & 59 & (79.7) & 45 & $(60.8)$ & 38 & (51.4) & 21 & (28.4) & 32 & $(43.2)$ & 9 & (12.12) & 4 & (5.3) \\
\hline
\end{tabular}

MF: Mycosis fungoides, PTC NOS, ATLL: Adult T-cell leukemia/lymphoma, CD30+: CD30+ lymphoproliferative disorders, HVL: Hydroa vacciniforme like-lymphoma, NTCL: NK/T-cell lymphoma. 


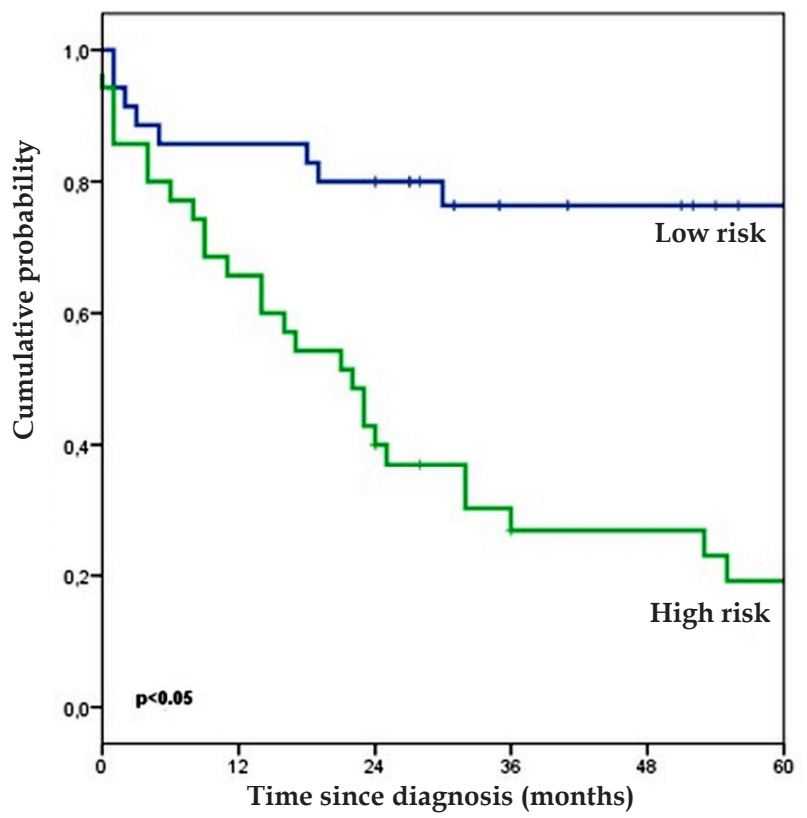

$\begin{array}{rcccccc}\text { Low risk: } & 100 \% & 85.7 \% & 80 \% & 76.4 \% & 76.4 \% & 76.4 \% \\ \text { n: } & 35 & 30 & 28 & 17 & 15 & 11 \\ \text { Righ risk } & 100 \% & 65.7 \% & 40 \% & 26.9 \% & 26.9 \% & 19.2 \% \\ \text { n: } & 35 & 23 & 15 & 9 & 7 & 5\end{array}$

WHO: World Health Organization, EORTC: European Organization for Research and Treatment of Cancer

GRAPH 2: Overall survival by risk groups according to the WHO-EORTC classification (2005)

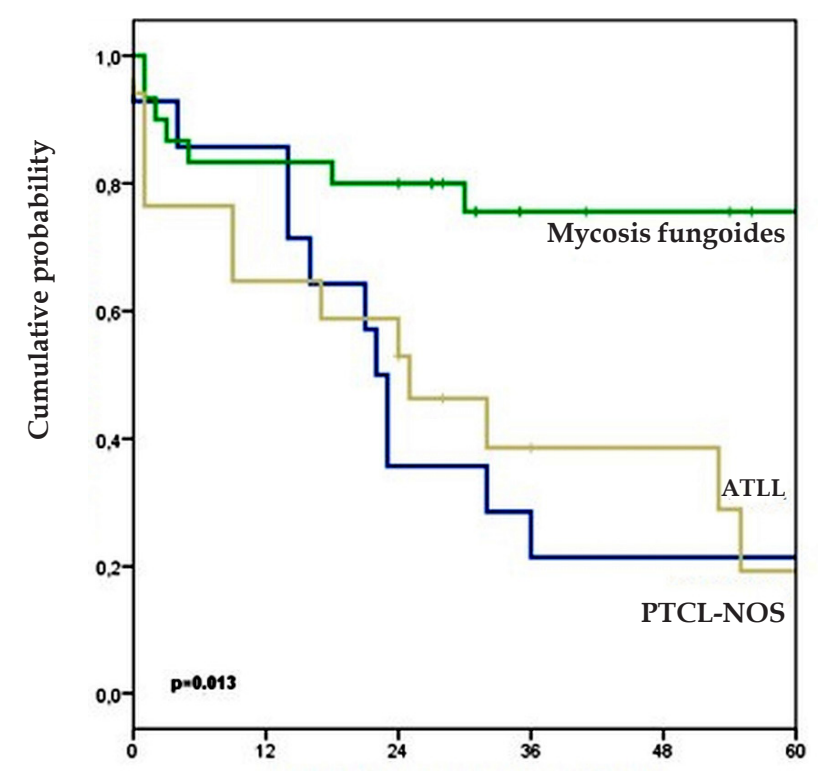

Time since diagnosis (months)

$\begin{array}{rcccccc}\text { Mycosis fungoides: } & 100 \% & 83.3 \% & 80 \% & 75.6 \% & 75.6 \% & 75.6 \% \\ \mathbf{n}: & 30 & 25 & 24 & 13 & 12 & 10 \\ \text { ATLL } & 100 \% & 85.7 \% & 35.7 \% & 21.4 \% & 21.4 \% & 21.4 \% \\ \mathbf{n}: & 14 & 12 & 5 & 4 & 3 & 3 \\ \text { PTCL-NOS } & 100 \% & 64.7 \% & 52.9 \% & 38.6 \% & 38.6 \% & 19.3 \% \\ \mathbf{n}: & 17 & 11 & 10 & 5 & 4 & 2\end{array}$

MF: Mycosis fungoides, PTC NOS, ATLL: Adult T-cell leukemia/lymphoma.

GRAPH 3: Overall survival for MF, PTCL-NOS and ATLL nance of T-cell lymphomas over B-cell type. ${ }^{13,14}$ However, an US epidemiological study based on the SEER data - which evaluated 3,884 cutaneous lymphoma according to the WHO-EORTC classification - found that only $71.3 \%$ of cases corresponded to T-cell lymphomas. ${ }^{5}$ Our results, in accordance with previous regional studies, reaffirm that lymphoproliferative diseases distribution varies among geographical areas in relation to genetic and environmental factors. ${ }^{15}$

MF is the most frequent cutaneous lymphoma in our country and worldwide. ${ }^{3,5,11}$ It is a disease that typically affects elderly people (mean age at the time of diagnosis: 55-60 years) and exhibits an indolent course with a slow progression of years or decades, from patchy lesions to more infiltrated plaques and eventually to tumors, or a combination of these. Initial lesions are more likely to appear on the buttocks and other areas that are not exposed to sunlight. Tumors rarely appear at the beginning of the disease; therefore, when facing this scenario, another primary cutaneous lymphoma type should be considered in the differential diagnosis. At advanced stages of the disease, there might be also nodal or even visceral involvement. ${ }^{10}$ Five-year OS is over $80 \%{ }^{5,10}$ The present series reports that most of our cases corresponded to this entity. Our OS at five years was $75.6 \%$, similar to the $77 \%$ reported in a Peruvian case series. ${ }^{11}$ Disseminated disease, tumoral stage, and histologically documented nodal involvement are adverse prognosis factors for survival. ${ }^{16,17}$

Remarkably, ATLL and extranodal NTCL represented 18.9\% and $4.1 \%$ of our cases, respectively, contrary to what is reported in Western countries, where these lymphomas account for less than $1 \% .5,10$

HTLV-1 infection is necessary, yet not sufficient, to develop ATLL. This disease arises in $1 \%$ to $5 \%$ of seropositive individuals, usually after two decades of viral persistence. ${ }^{10}$ An area is denominated endemic for this retrovirus when $2 \%$ to $10 \%$ of the healthy adult population is infected. ${ }^{18}$ Around the world, Japan, the Caribbean islands, certain regions of Africa and South America (Brazil, Colombia and Peru) are considered endemic areas. ${ }^{19}$ In our country, the mean prevalence in general population selected groups is $5.19 \% .^{18}$ The ATLL high frequency found in this study reflects HTLV1 endemicity in our environment, especially in the Highlands.

In 1991, Shimoyama categorized ATLL in 4 subtypes: acute or leukemia, lymphoma, chronic and smoldering. ${ }^{20}$ Cutaneous involvement caused by ATLL is polymorphic and appears in around $50 \%$ of the patients and in every clinical subtype. ${ }^{8}$ In certain cases, the skin is the only affected organ at the time of diagnosis. Some authors consider this cases as primarily cutaneous ATLL forms, designating them "cutaneous ATLL". ${ }^{21,22}$ Despite being classified as smoldering type according to Shimoyama, the prognosis of cutaneous ATLL is poor, with a mean survival time of 30 months, compared with 35 months for the smoldering type without cutaneous involvement. ${ }^{22}$ Indeed, Yamaguchi proposed two "cutaneous ATLL" subtypes; erythematous papular and tumoral, with means survival time of 60 and 19 months, respectively. ${ }^{21}$ In our country, Beltrán reported a 5 -year OS of $18 \%$ for cutaneous ATLL; comparable with ours of $21.4 \%$ (mean survival time, 22 months).$^{11}$ These results may be attributed to the inclusion of ATLL cases that rapidly developed systemic involvement after diagnosis and therefore would actually correspond to ATLL leukemia, lymphoma or chronic types. That is why for some authors, the PCL definition excludes the progression 
to extracutaneous locations in the six months following the diagnosis. ${ }^{23}$ Even though this is a more realistic definition, it is not practical, given that its application is merely retrospective and does not allow making decisions when diagnosing. In our experience, exclusive cutaneous affectation caused by ATLL constitutes the exception and not the rule. It is important to consider that in most of the cases, cutaneous involvement caused by ATLL occurs within the frame of a generalized and rapidly progressive disease.

NTCL constitutes another entity that occurs more frequently in Asian Central and South American populations, including Peru. ${ }^{15,24}$ NTCL mainly presents with extra-nodal involvement (70\% to $90 \%$ of cases), predominately in the nasal region and upper aerodigestive tract, followed by skin, gastrointestinal tract and testicles. ${ }^{24,25}$ In the skin, this disease is characterized by multiple nodules or tumors, frequently ulcerated and predominantly in trunk and limbs. ${ }^{26}$ It may be associated with systemic symptoms such as fever and weight loss. ${ }^{10}$ Epstein-Barr virus (EBV) is integrated in tumoral cells in almost all the cases, strongly suggesting its pathogenic role in the disease. ${ }^{25}$ This is an aggressive entity that tends to disseminate and whose mean survival time is 15 months. ${ }^{27}$ In our series, the three patients with cutaneous NTCL died before a year since diagnosis.

HVL is a rare NK/T lymphoma with variable behavior.8 It mainly affects children and teenagers from Asia or Latin-American, although it may exceptionally affect adults. ${ }^{28}$ Clinically, it is characterized by the presence of rash, edema, vesicles, ulcers, crusts and scars; particularly on the face and occasionally on the limbs. ${ }^{28}$ There is a strong association with the latent infection caused by EBV, which is detected through in situ hybridization (ISH) or by poly- merase chain reaction (PCR) in $80 \%$ to $100 \%$ of patients. ${ }^{29}$ The four reported cases in the present series were 15, 17, 23 and 26 years old and represented a significant $5.4 \%$ of the patients of our study. Evolution of the disease was variable, with 3 patients still alive and one dying due to the disease. Further investigation is required in order to determine the optimal treatment for this pathology, and if there are differences in the biological behavior among the pediatric and adult patients.

The term PTCL-NOS is used to classify all those entities that do not fit in the other well-defined subtypes of T-cell lymphomas primary to the skin. It probably includes many entities, but for now, criteria and biomarkers in order to recognize them are lacking. It usually appears on adults, with solitary nodules, and more frequently, with generalized nodules or tumors. ${ }^{30}$ In general, these cutaneous lymphomas have a poor prognosis. ${ }^{31}$ In this series, they accounted for $23 \%$ of the cases with a 5 -year OS of $19 \%$. As in ATLL, we consider that within this group, patients who presented only with cutaneous disease but rapidly progressed into a systemic involvement were included.

\section{CONCLUSION}

PCTCL constitutes a heterogeneous group of entities with different clinical and histopathological characteristics and prognosis and with particular geographic variations. PCTCLs different from $\mathrm{MF}$ or $\mathrm{CD} 30+$ lymphoproliferative disorders, are aggressive entities with a dismal prognosis.]

\section{REFERENCES}

1. Willemze R, Hodak E, Zinzani PL, Specht L, Ladetto M; ESMO Guidelines Working Group. Primary cutaneous lymphoma: ESMO clinical recommendations for diagnosis, treatment and follow-up. Ann Oncol. 2013;24:vi149-54.

2. Grange $F$, Hedelin G, Joly $P$, Beylot-Barry M, D'Incan M, Delaunay M, et al. Prognostic factors in primary cutaneous lymphomas other than mycosis fungoides and the Sézary syndrome. The French Study Group on Cutaneous Lymphomas. Blood. 1999;93:3637-42.

3. Willemze R. XV. Primary cutaneous lymphomas. Ann Oncol (2011);22 (suppl_4): iv72-iv75. doi: 10.1093/annonc/mdr181

4. Groves FD, Linet MS, Travis LB, Devesa SS. Cancer surveillance series: nonHodgkin's Iymphoma incidence by histologic subtype in the United States from 1978 through 1995. J Natl Cancer Inst. 2000;92:1240-51.

5. Bradford PT, Devesa SS, Anderson WF, Toro JR. Cutaneous lymphoma incidence patterns in the United States: a population-based study of 3884 cases. Blood. 2009;113:5064-73.

6. Valdez JJP, Perez VV, Ojeda DV. Características epidemiológicas, clínicas y patológicas de los linfomas en el Hospital Nacional Cayetano Heredia del año 1998 al 2008. Acta Med Per. 2011;28:12-8.
7. Chang A, Seminario V, Navarrete J, Melendez R, Torres E, Barrionuevo C. Linfomas extraganglionares en Lima Metropolitana. An. Fac. Med. 2001;62:193-9.

8. Swerdlow SH, Campo E, Harris NL, Jaffe ES, Pileri SA, Stein H, et al. WHO Classification of Tumours of Haematopoietic and Lymphoid tissues. 4th ed. Lyon, France: IARC Press; 2008.

9. Bagot M, Ortonne N. Linfomas cutáneos: clasificación. EMC - Dermatología 2013;47:1-6.

10. Willemze R, Jaffe ES, Burg G, Cerroni L, Berti E, Swerdlow SH, et al. WHO-EORTC classification for cutaneous lymphomas. Blood. 2005;105:3768-85.

11. Gárate1 BB, Luna DM, Ávila PQ, Mendoza FH, Gonzales LR, Berocal AY, et al Linfomas Cutáneos primarios: estudio retrospectivo clinicopatológico durante el periodo 1997-2004 en el Hospital Edgardo Rebagliati Martins, Essalud, Lima, Perú. Acta Med Per. 2008;25:81-4.

12. Bittencourt AL, Oliveira PD, Andrade AC, Santos TC, Oliveira RF, Farré L, et al. Analysis of cutaneous lymphomas in a medical center in Bahia, Brazil. Am J Clin Pathol. 2013;140:348-54.

13. Nagasawa T, Miwa H, Nakatsuka S, Itami S, Yoshikawa K, Aozasa K Characteristics of cutaneous lymphomas in Osaka, Japan (1988-1999) based on 
the European Organization for Research and Treatment of Cancer classification. Am J Dermatopathol. 2000;22:510-4.

14. Fujita A, Hamada T, Iwatsuki K. Retrospective analysis of 133 patients with cutaneous lymphomas from a single Japanese medical center between 1995 and 2008. J Dermatol. 2011;38:524-30.

15. Chang D, Zerbini MC, Sotto MN, Siqueira SA, Sanches JA. Evaluation of the 2008 World Health Organization classification for non-mycosis fungoides, non-Sezary syndrome T/NK-cell lymphomas with primary cutaneous involvement. J Cutan Pathol. 2015;42:965-73

16. van Doorn R, Van Haselen CW, van Voorst Vader PC, Geerts ML, Heule F, de Rie M, et al. Mycosis fungoides: disease evolution and prognosis of 309 Dutch patients. Arch Dermatol. 2000;136:504-10.

17. Kim YH, Liu HL, Mraz-Gernhard S, Varghese A, Hoppe RT. Long-term outcome of 525 patients with mycosis fungoides and Sezary syndrome: clinical prognostic factors and risk for disease progression. Arch Dermatol. 2003;139:857-66.

18. Gotuzzo E, Verdonck K, González E, Cabada M. Virus Linfotrópico Humano de Células T tipo 1 (HTLV-1): Una infección endémica en el Perú. Rev Peru Med Exp Salud Publica. 2004:21:253-60.

19. Gonçalves DU, Proietti FA, Ribas JG, Araújo MG, Pinheiro SR, Guedes AC, et al. Epidemiology, Treatment, And Prevention Of Human T-Cell Leukemia Virus Type 1-Associated Diseases. Clin Microbiol Rev. 2010;23:577-89.

20. Shimoyama M. Diagnostic criteria and classification of clinical subtypes of adult T-cell leukaemia-Iymphoma. A report from the Lymphoma Study Group (198487). Br J Haematol. 1991;79:428-37.

21. Johno M, Ohishi M, Kojo Y, Yamamoto S, Ono T. Cutaneous manifestations of adult T-cell leukemia/lymphoma. In Advances in Adult T-Cell Leukemia and HTLV-I Research (Gann Monograph on Cancer Research 39). Tokyo: Japan Scientific Societies Press; 1992. p. 33-42.

22. Yamaguchi T, Ohshima K, Karube K, Tutiya T, Kawano R, Suefuji $\mathrm{H}$, et al. Clinicopathological features of cutaneous lesions of adult T-cell leukaemia/ lymphoma. Br J Dermatol. 2005:152:76-81.

23. Willemze R, Kerl H, Sterry W, Berti E, Cerroni L, Chimenti S, et al. EORTC classification for primary cutaneous lymphomas: a proposal from the Cutaneous Lymphoma Study Group of the European Organization for Research and Treatment of Cancer. Blood. 1997;90:354-71.

24. Kwong YL. Natural killer-cell malignancies: diagnosis and treatment. Leukemia. 2005;19:2186-94.

25. Chan JK, Sin VC, Wong KF, Ng CS, Tsang WY, Chan CH, et al. Nonnasal lymphoma expressing the natural killer cell marker CD56: a clinicopathologic study of 49 cases of an uncommon aggressive neoplasm. Blood. 1997;89:4501-13.

26. Kato $\mathrm{N}$, Yasukawa $\mathrm{K}$, Onozuka T, Kikuta $\mathrm{H}$ Nasal and nasal-type T/NK-cell lymphoma with cutaneous involvement. J Am Acad Dermatol. 1999:40:850-6.

27. Natkunam Y, Smoller BR, Zehnder JL, Dorfman RF, Warnke RA. Aggressive cutaneous NK and NK-like T-cell lymphomas: clinicopathologic immunohistochemical, and molecular analyses of 12 cases. Am J Surg Pathol. 1999;23:571-81.

28. Barrionuevo C, Anderson VM, Zevallos-Giampietri E, Zaharia M, Misad O, Bravo F et al. Hydroa-like cutaneous T-cell lymphoma: a clinicopathologic and molecular genetic study of 16 pediatric cases from Peru. Appl Immunohistochem Mol Morphol. 2002;10:7-14.

29. Iwatsuki K, Xu Z, Ohtsuka M, Kaneko F. Cutaneous lymphoproliferative disorders associated with Epstein-Barr virus infection: a clinical overview. J Dermatol Sci. 2000;22:181-95

30. Bekkenk MW, Vermeer MH, Jansen PM, van Marion AM, Canninga-van Dijk MR, Kluin PM, et al. Peripheral T-cell lymphomas unspecified presenting in the skin: analysis of prognostic factors in a group of 82 patients. Blood. 2003;102:2213-9.

31. Jaffe ES. The 2008 WHO classification of Iymphomas: implications for clinical practice and translational research. Hematology Am Soc Hematol Educ Program. 2009:523-31.
MAILING ADDRESS:

Rosana Ruiz

Angamos Este 2520

Surquillo

Lima, Peru.

Email: rossana_rm@hotmail.com

How to cite this article: Ruiz R, Morante Z, Mas L, Casanova L, Gomez H. Primary cutaneous T-cell lymphoma: experience from the Peruvian national cancer institute. An Bras Dermatol. 2017;92(5):649-54. 